北大景观对于

中国传统生态智慧及其复兴的研究

\section{LA PKU'S RESEARCH ON \\ CHINA'S TRADITIONAL \\ ECO-WISDOM AND \\ RELATED APPLICATION IN \\ CONTEMPORARY LANDSCAPE PLANNING AND DESIGN}

1 概述

生态智慧在解决中国当代生态问题、践行生态文明建设的过程中 扮演着重要角色 ${ }^{[1] 2]}$ 。在拥有几千年农耕文明历史的中国，古代先民积 累了极为丰富的经验知识与实践, 对于发展属于当代的生态智慧具有 重要参考和借鉴意义 ${ }^{[3]}$ 。对中国传统生态智慧的研究吸引了生态学、地 理学、民族学, 以及资源环境、城乡规划建设、水利等学科的关注, 正蓬勃发展为一个多学科交叉的研究领域。

北大景观 ${ }^{\circledR}$ 从1997年成立伊始，一直坚持在景观规划设计的教学、 研究与实践中尊重土地以及土地之上的自然和历史文化过程。从早期 的“风水” 和理想景观研究, 到乡土景观视野下对乡土聚落、农业景
https://doi.org/10.15302/J-LAF-20180302 收稿时间 RECEIVED DATE/ 2018-05-20 中图分类号/ TU98 文献标识码/A

\section{张蕾}

天津大学建筑学院建筑历史与理论研究所讲师 天津市南开区卫津路92号天津大学建筑学院 3001 , 邮编: 300072

zhang lei_gsla@126.com

摘要

自1997年起, 北大景观研究团队对中国传 统生态智慧及其复兴开展了一系列研究。本文首 先梳理了这些研究的背景和发展历程: 早期的研 究主要关注 “风水” 和乡土景观, 源于在规划设 计实践中理解和回应地方自然与人文过程; 2006 年, 俞孔坚提出景观设计学是一门 “生存的艺 术” 的学科定位, 推进了对传统 “生存的艺术” 的研究及其复兴, 旨在为当代景观设计学寻找历 史根基, 并将研究成果用于解决当代生态环境问 题; 2014年, “生存的艺术”的研究被进一步推

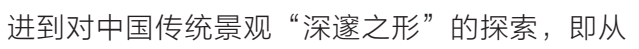
形式语言与微观和场地尺度的设计策略等角度深 入研究传统景观, 从中提炼出可用于当代景观设 计的语言。在此基础上, 本文回顾总结了北大景观 在过去20年间取得的主要研究成果, 包括传统农 业景观、乡土聚落、传统水适应性景观三个方面。

关键词

北大景观; 生态智慧; 景观规划设计; 乡土景 观; 生存的艺术; 水适应性景观

\section{Lei ZHANG}

Lecturer at the Institute of Architectural History and Theory. School of Architecture, Tianjin University

\section{ABSTRACT}

Since 1997, LA PKU has conducted a series of studies on China's traditional ecological wisdom and related application in contemporary landscape planning and design. This paper first reviews the background and the course of LA PKU's research: In early years, they studied on Feng-shui and vernacular landscapes that stemmed from their understanding and response to local natural and human processes in planning and design practice; In 2006, Kongjian Yu proposed the concept that Landscape Architecture is a discipline concentrating on the art of survival, which has greatly promoted the study and revival of traditional eco-wisdom, not only providing a historical base for the modern development of Landscape Architecture, but also applying the research results in responding to contemporary environmental and ecological problems; In 2014. developed upon the achievement on the art of survival, LA PKU further explored the deep form of China's traditional landscapes by studying local spatial forms and design strategies on micro- and site-scales and translating such ecological solutions into China's contemporary landscape design. The paper also reviews on LA PKU's important research results over the past two decades, including traditional agricultural landscapes, vernacular settlements, and traditional water-adaptive landscapes.

\section{KEY WORDS}

LA PKU; Ecological Wisdom; Landscape Planning and Design; Vernacular Landscape; Art of Survival; Water-Adaptive Landscape

\section{基金项目:}

国家自然科学基金资助项目 (编号: 51608355 )

Research Fund:

National Natural Science Foundation of China (No. 51608355)

整理 田乐 汪默英 译田乐

EDIted By Tina TIAN Moying WANG tRansLated Tina tIAN 
"LA PKU" is a collective name short for the research team of the College of Architecture and Landscape Architecture of Peking University founded in 2010, which was in 2010, which was developed from the Center for Landscap Architecture and Planning of Peking University established in 1997 and then the Graduate School of Landscape Architecture of Peking University founded in 2003. LA PKU has a long-term and close collaboration with Turenscape on landscape planning an design practice. In this paper, all the planning and design works are done by LA PKU and Turenscape, unless noted otherwise.
观等的研究, 再到近年来对传统水适应性景观的研究, 北大景观对 中国不同区域、不同类型的传统景观以及与之相关的传统生态智慧 开展了大量研究, 并探索在当代生态规划设计中复兴、借鉴传统智 慧的有效途径。本文尝试对上述研究的发展历程与研究成果进行回顾 和总结。

\section{2 研究历程}

北大景观对中国传统生态智慧及其复兴的研究历程大致可以分为 三个阶段:

\section{1 从理解 “风水” 到乡土景观研究 (1990年代至2006年)}

北大景观对中国传统生态智慧的研究, 可以追溯到俞孔坚于 20 世 纪90年代开展的 “风水”与理想景观研究 (图1)。通过对 “风水”, 以及诸如桃花源、传统山水画、蓬莱仙境等一系列中国古代理想景观 的比较研究, 俞孔坚指出, 在这些被宗教、哲学、美学, 甚至迷信和 神秘主义所笼罩的文化表象背后，是一种带有共性的中国文化中的理 想景观模式，其反映了在中国特有自然地理环境下、以农耕文明为主 导的中华民族的生存经验与环境适应经验。他进而强调了在景观规划 设计中, 应当充分理解并尊重这些传统文化信仰, 并尊重当地的自然 与文化进程。 ${ }^{[4]}$

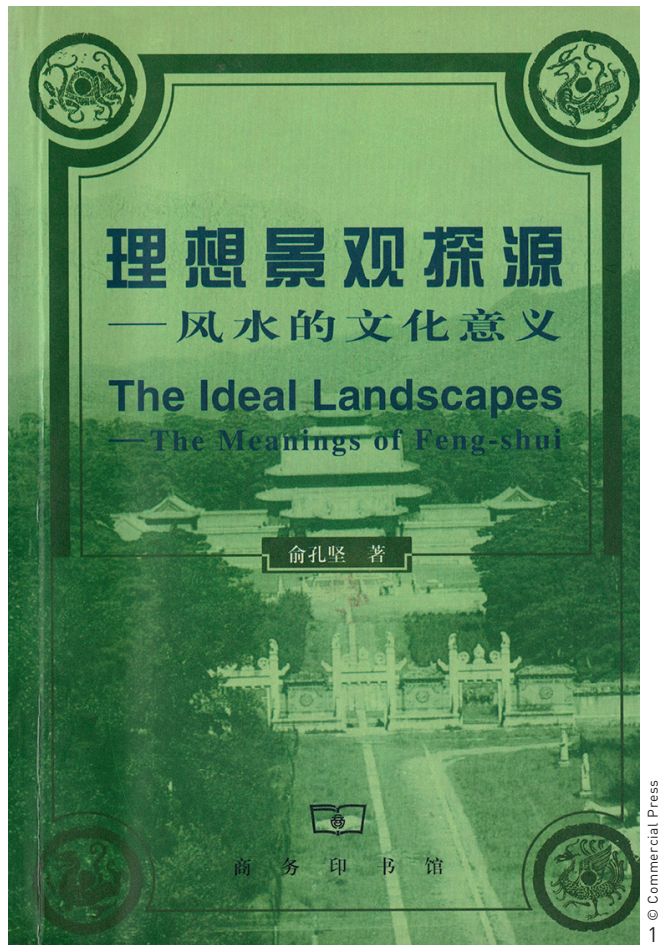

《理想景观探源一一 水的文化意义》封面 该书于1998年出版。

1. Cover of The Ideal Landscapes - The Meanings of Feng-shui, published in 1998.

\section{Introduction}

Ecological wisdom contributes a lot to addressing the contemporary ecological issues and the agenda of Ecological Civilization Construction in China ${ }^{[1][2]}$. The ancient Chinese accumulated a wealth of experience and knowledge of ecological practice in the agricultural civilization for generations, which still holds a significance for developing contemporary ecowisdom ${ }^{[3]}$. Currently, research on China's traditional eco-wisdom has been conducted in interdisciplinary fields between ecology, geography, ethnology, resource and environment, urban and rural planning and construction, water conservancy, etc.

Since 1997, in the efforts of LA PKU ${ }^{1}$ in landscape planning and design education, research, and practice, they have advocated to respect the land we live and the related natural, historical, and cultural processes. From the early research on Feng-shui and ideal landscapes, to the studies on vernacular settlements and agricultural landscapes, and the recent studies on traditional water-adaptive landscapes, LA PKU's research covers a wide variety of traditional landscapes across the country and the related eco-wisdom, and explores effective ways to rejuvenate such wisdom in contemporary ecological planning and design. This paper reviews the relevant history and research results of LA PKU in the past two decades.

\section{Research Course}

The course of LA PKU's research on China's traditional ecowisdom and related application in contemporary landscape planning and design can be divided into three stages:

\subsection{From Feng-shui Study to Vernacular Landscape Research (1990s to 2006)}

LA PKU's research on China's traditional eco-wisdom started from the study on Feng-shui and ideal landscapes by Kongjian $\mathrm{Yu}$ in the 1990s (Fig. 1). Through a series of comparative studies on Feng-shui and ancient Chinese ideal landscapes such as the Land of Peach Blossoms, traditional landscape paintings, and the Penglai Wonderland, Yu pointed out that in Chinese culture, beyond the veil of religious, philosophical, aesthetical, or even superstitious, mysticism implications, these landscapes were all typical ideal landscapes reflecting the survival of ancient Chinese people and their experience adapting to the natural environment in the age of agricultural civilization. He further argued that such traditional cultural or religious beliefs, as well the related natural and cultural processes, should be well understood and respected in landscape planning and design. ${ }^{[4]}$ 
1998年以后，北大景观对 “风水” 的关注被拓宽至乡土景观实证 性研究与保护实践层面。乡土景观是指长期自发形成的、与当地人日 常生产生活相关、且适应当地气候与地理环境的自然与文化景观综合 体。乡土景观反映着真实的人地关系, 蕴含着丰富的环境适应经验与 智慧。但中国当代景观设计师往往醉心于各种新奇的、外来的风格, 而对乡土景观重视不足。俞孔坚提出的“乡土景观研究倡议” , 除了 重视从历史遗产角度对乡土景观进行发掘、整理与保护, 更强调 “寻 常”乡土对于当代景观设计的启示意义。 ${ }^{[5][6]}$ 在这一时期, 北大景观 重点关注乡土景观中农业景观与乡土聚落两个方向, 以及其中人与自 然相和谐的传统经验与物质形式, 并将研究成果融人到当代规划设计 实践中, 从而创造出了具有地域特色、符合生态需求和可持续原则的 “新乡土景观” [7]。

\section{2 “生存的艺术” 与传统水适应性景观研究（2006 2014年）}

2004年，受印度洋海啸灾害触动，俞孔坚开始关注在当代日益严 峻的环境与生态危机下人类的生存问题，并思考景观设计学科和专业 在应对这些危机时所应扮演的角色。在2006年举行的国际景观设计师 联盟（IFLA）东区会议，以及同年10月举行的2006美国景观设计师协 会年会暨第43届IFLA世界大会上，俞孔坚提出了“生存的艺术一 重新定位当代景观设计学” 的思想（图2）。他指出, 景观设计学不 是 “种花种草”, 而是一门关于土地设计与监护的 “生存的艺术”, 是应对和解决当代中国环境与生态危机及文化身份认同危机的重要途 径。景观设计学的根基不仅仅是传统园林艺术，更是 “我们的祖先在 谋生过程中积累下来的种种生存的艺术的结晶, 这些艺术来自对于各 种环境的适应, 来自于探寻远离洪水和敌人侵扰的过程, 来自于土地 丈量、造田、种植、灌溉、储蓄水源和其他资源而获得可持续的生存 与生活的实践”。 ${ }^{[8]}$

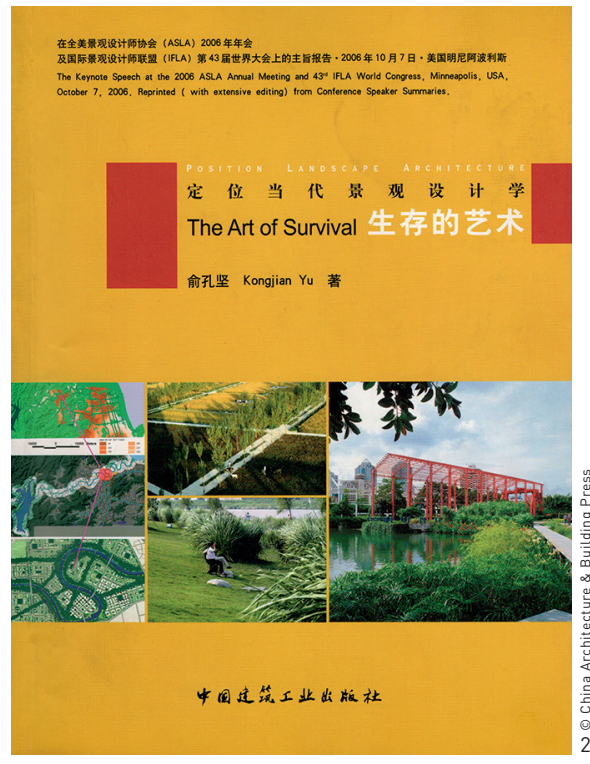

2. 《生存的艺术一一定 位当代景观设计学》 封面, 该书中英文版于 2006年出版。

2. Cover of The Art of Survival Position Landscape Architecture, published in English and Chinese in 2006.
Since 1998, LA PKU's study on Feng-shui had expanded to the empirical research and protection of vernacular landscapes. Formed spontaneously by inhabitants' productive activities and daily life, vernacular landscape is a natural and cultural landscape complex that adapts to local climate, natural environment, and geographical settings. Such landscapes reflect a real human-land relationship and a wealth of environmentadaptive experience and wisdom. However, contemporary Chinese landscape architects are often obsessed with novel, exotic landscapes while less regarding to vernacular landscapes. In his Vernacular Landscape Research Initiative, Yu not only attached the importance to explore, study, and protect vernacular landscapes as historic heritages, but also underlined the significance what we can learn from such "ordinary" landscapes for contemporary landscape design. ${ }^{[5][6]}$ In this stage, LA PKU focused on studying traditional agricultural landscapes and vernacular settlements, as well as the physical forms shaped through the harmonious human-land interactions and the related eco-wisdom. They also had applied these research results into contemporary planning and design practice to create new vernacular landscapes that celebrate regional characteristics and realize sustainable visions ${ }^{[7]}$.

\section{2 "The Art of Survival" and Research on Traditional Water-} Adaptive Landscapes (2006 2014)

Affected by the Indian Ocean tsunami disaster in 2004 Yu began to pay attention to human survival challenged by increasingly severe environmental and ecological crises, and considered the role that Landscape Architecture and the landscape design profession should play in responding to the crises. On the 2006 IFLA (International Federation of Landscape Architects) Eastern Region Conference and the 2006 ASLA (American Association of Landscape Architects) \& the 43rd IFLA Annual Conference, Yu proposed a concept of "the art of survival to reposition Landscape Architecture in the new era" (Fig. 2), arguing that landscape design is not about vegetation planting, but an art of survival that designs and protects the land we live on, offering important approaches to address environmental and ecological issues and the loss of cultural identity in contemporary China. He believed that the foundation of Landscape Architecture should go beyond the art of traditional garden making to the art of survival that has been accumulated by generations and generations through their practice to adapt to environmental changes, to stay away from floods and enemies, and to measure, reclaim, plant, irrigate, save water and other resources to survive and make a good living. ${ }^{[8]}$ 
以上思想为中国传统景观研究赋予了崭新且更为重要的使命, 即跳出传统园林史的范畴，从包括历史地理、农业史、水利史、环境 史、城镇建设史等多学科的视野下展开研究, 重新发现那些中国大地 上古已有之的 “生存的艺术” , 为当代景观设计学建立历史根基, 同 时为解决当代环境与生态问题提供参照与借鉴。

由此, 北大景观开始更加系统化、主题鲜明地对中国传统景观展 开研究。其中关于传统水适应性景观的研究成果最为突出, 它集中反 映了北大景观对当代最为尖锐和紧迫的水问题的研究与探索。当代中 国大面积国土面临着洪涝灾害、水资源短缺、水污染、水生态恶化等 综合性水问题，全球气候变化和快速城镇化使得上述问题越发严峻, 以往单纯依赖水利工程的做法已难以应对这些挑战, 函需寻找一种更 加可持续的新策略。对此, 中国劳动人民在漫长历史实践中积累的水 适应与水管理经验具有重要的借鉴意义。围绕这一主题, 北大景观开 展了一系列针对长江三角洲、珠江三角洲、黄泛平原、西北干旱区、 西南山区等不同地域，涉及农田和农田水利景观、江河水利、传统城 镇等不同类型的传统水适应性景观研究。研究成果为建设 “海绵城 市”、提高当代中国城市水适应能力、构建国土和区域水生态基础设 施等研究与规划设计实践提供了重要的历史参照。

\section{3 探索传统景观的“深遂之形”（2014年至今）}

2014年2月，在由景观生态规划学者弗雷德里克・斯坦纳召集、汇 集了多位该领域知名学者的 “自然与城市：城市生态设计与规划” 研 讨会上，俞孔坚做了题为 “创造都市自然的深遂之形：农民的途径” 的报告, 提出研究和复兴中国传统智慧、创造当代景观的 “深遂之 形”。“深遂之形”一词源于约翰 - 莱尔对人类生态系统所具有的深 层形式的阐述。莱尔认为，自然过程与人类活动共同塑造了景观的形 式，这些形式植根于且展现了人类生态系统的内在秩序，因而是深遂 的 ${ }^{[9]}$ 。简言之, “深遂之形” 是指建立在完整的生态过程之上、能够保 障生态健康与安全的景观形式。与之相对的是当代城市景观中广泛存
This concept has given a new and more important meaning to the study on China's traditional landscapes that is to encourage multidisciplinary research in historical geography, agricultural history, water history, environmental history, urban construction history, etc. in order to not only establish a historical base for modern Landscape Architecture, but also to revive the art of survival and offer reference to dealing with contemporary environmental and ecological problems.

Since then, LA PKU started to study China's traditional landscapes in a more systematic and theme-based way. Among their research, the achievement on traditional water-adaptive landscapes was outstanding and represented LA PKU's exploration of addressing the most complicated and pressing water problems in China, including flood, water shortage, water pollution, and degradation of aquatic ecosystems. Nowadays, in the context of global climate change and rapid urbanization, these crises are challenging humans' survival more seriously than ever before, and the conventional engineering approaches fail to cope with. More sustainable approaches are urgently needed. In this regard, the ancient eco-wisdom accumulated through Chinese ancestors' practice of water adaptation and management might offer solutions. LA PKU launched a series of research on various traditional water-adaptive landscapes throughout China, including farmlands, water-related agricultural infrastructures, and traditional town landscapes in Yangtze River Delta, Pearl River Delta, Yellow River Flood Plain, the arid region in Northwest China, and the mountainous region in Southwest China. These research has inspired many landscape planning and design projects in the Sponge City Construction, the improvement of water-adaptive capacity of contemporary Chinese cities, and the construction of ecological water infrastructures at regional- and national-scales.

\subsection{Exploring the Deep Forms of Traditional Landscapes (2014 to Present)}

In February 2014, on the Conference of Nature and Cities: Urban Ecological Design and Planning, convened by landscape and ecological planning scholar Frederick Steiner, a number of leading scholars, planners, and designers were gathered to address how ecological design and planning remain integral links in the betterment of the world's cities. In his speech Creating Deep Forms in Urban Nature: The Peasants' Approach to Urban Design, Yu raised a concept to rejuvenate China's ancient wisdom to create the "deep forms" of contemporary landscapes. The term "deep form" stems from John Lyle's words explaining the deep forms of human ecosystem. Lyle believed that natural processes and human practices together shape the forms of 
在的浅层的或肤浅的形式，它们脱离了内在自然过程的支撑，切断了 人与自然的联系 ${ }^{[10]}$ 。

俞孔坚认为, 依靠景观生态学、地理信息系统等科学和技术手段 有助于我们在宏观尺度上识别建立在自然过程及其空间格局上的 “深 遂之形” ，但一个难题是如何在微观和场地的尺度上设计人工与自然 有机叠合的景观形态。俞孔坚认为, 我们应当向那些建立在人与土地 最为紧密的联系之上的传统农业实践学习; 我们应当研究这些传统的 生态实践如何改变自然景观，如何创造丰富多样的、具有启示意义的 “深遂之形”，并从中汲取设计策略和形式语言，通过与当代的科 学、技术与艺术相结合来创造当代城市景观的 “深遂之形”。[9[10]

基于以上认识，俞孔坚对传统农业实践中创造的“深遂之形”的 景观营造与管理行为进行了总结, 包括造田、灌溉、施肥和栽植，它 们对当代城市景观中的雨水管理、防洪治涝、污水处理、有机废物循 环利用、棕地修复、乡土植被修复、都市农业等都具有重要的借鉴意 $义^{[3] \mid 9]}$ 。由此, 北大景观对中国传统生态智慧的研究进人了纵深发展阶 段, 即从微观和场地尺度上的设计策略及形式语言等角度研究传统景 观, 总结提炼设计语言, 并将其融人当代景观规划设计之中一一这将 成为北大景观未来最值得期待的研究方向之一。

\section{4 复兴传统智慧，探索当代生态问题和城市问题解决方案}

从理解乡土景观（主要集中于农业景观和乡土聚落），到研究 “生存的艺术”（主要集中于传统水适应性景观），再到探索传统景 观的 “深遂之形” , 这些聚焦于中国传统生态智慧的研究, 源于北大 景观对当代生态问题和城市问题的思考，也最终回到服务于当代问题 的解决, 使传统智慧研究不仅停留在挖掘历史遗产的层面, 更延伸到 规划设计实践中的应用层面，从而得到真正意义上的复兴和发展。

因此, 北大景观坚持以应用为导向开展研究, 探索如何将传统生 态智慧应用于指导当代景观规划设计，并在实践中认识到：由于社会 our landscapes. These forms are rooted in and reveal the deep, inherent order of human ecosystems ${ }^{[9]}$. In short, opposite to the shallow forms widely seen in the contemporary urban landscapes that break the inherent natural process and the human-nature connection, a deep-form landscape exists on a complete ecological process and supports the health and safety of ecosystems ${ }^{[10]}$.

Yu believed that using scientific and technological approaches of Landscape ecology and the geographic information systems can help us identify the deep forms - the structure underlies in the natural processes and patterns - at regional- or macroscales. However, one real problem is how to overlap and design a landscape that combines natural and constructed elements on both micro- and site-scales. Yu argued that we should learn from traditional agricultural practices that established a close interaction between human and land; we also should explore how such practices have changed natural landscapes and created diverse deep forms, which would inspire us to design deep forms of contemporary urban landscapes by adopting related design strategies and spatial forms while integrating modern science and technology with art. ${ }^{[9][10]}$

Yu further examined the landscape construction and management activities and approaches that created the deep forms in traditional agricultural landscapes, including farmland reclamation, irrigation, fertilization, and planting, which offer references to stormwater management, flood control, sewage treatment, material recycle, brownfield remediation, biological restoration, and urban agriculture in modern cities ${ }^{[3][9]}$. During this stage, LA PKU's research on China's traditional eco-wisdom has shown a great progress in depth, focusing design strategies and landscape forms on micro- and site-scales and extracting design language to inform contemporary landscape planning and design - this is one of the most promising agendas of LA PKU's future research.

\subsection{Reviving Traditional Wisdom and Developing Solutions to Contemporary Ecological and Urban Issues}

From the study on vernacular landscapes (agricultural landscapes and vernacular settlements mainly), to the research on the art of survival (traditional water-adaptive landscapes mainly), and to the exploration on the deep forms of traditional landscapes, LA PKU's research interest on China's traditional ecowisdom stems from their concerns on contemporary ecological and urban issues and returns to developing efficient solutions. Beyond regarding such traditional eco-wisdom as a legacy, LA PKU has rejuvenated, applied, and developed them in a true sense.

Through the systematic study on China's traditional ecowisdom, LA PKU has focused on bridging research with practice 
3.《人民广场一一都江塭 广场案例》封面, 该书 于2004年出版。

4. 《田一人民景观叙事 南北案例》封面, 该书 于2005年出版。

3. Cover of People's Square - The Dujiangyan Square Case, published in 2004

4. Cover of Farmlands People's Landscapes throughout China, published in 2005
文化背景和经济技术条件的更迭，传统生态智慧有其时代局限性。但 同时，传统智慧也有其超越时代的共通性，例如与当代生态原则不谋 而合的适应自然环境、追求人地和谐等思想。因此, 复兴传统智慧需 要在当代背景下深刻理解上述差异和共通点, 结合当代的科学技术和 社会文化需求，对传统智慧进行创造性的提炼、转化和发展。

\section{3 研究成果}

\section{1 农业景观}

农业景观是中华文明所塑造的最具代表性的景观，曾经在中国大 地上造就了令人赞叹的 “诗情画意般的” 风景，也是可持续的生产与 生活、人地和谐的典范。传统农业景观中蕴含着丰富的有关景观的规 划设计、营造、管理的经验性知识，体现着适应、节制、循环利用等 传统生态哲学观念, 具有丰富多样的景观形态, 是当代景观设计思想 理论及形式语言的宝库 ${ }^{[1]}$ 。

北大景观早期的研究包括对云南红河地区哈尼族梯田景观对环境 的利用与适应的探讨, 如哈尼族人保护海拔 $2000 \mathrm{~m}$ 以上的高山森林, 以 吸纳降雨、涵养水源，灌溉山体中部的层层梯田 ${ }^{[122[13]}$; 川西平原的农业 景观集中体现了传统的治水智慧，以都江堰为中心的江河水利和田园 灌溉系统塑造了号称 “天府” 的富饶平原，对鱼嘴分水技术、漫水堰 坝、导水渡槽等一系列体现着传统智慧的典型水利景观的解读与再表

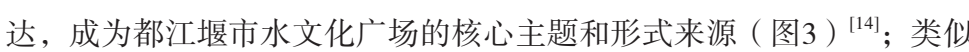
研究还包括传统滨水防护林景观 ${ }^{[15]}$ 、由防护林网和旱作农业构成的华北 平原农业景观 ${ }^{[16]}$ 、广东珠江三角洲地区顺德马岗桑基鱼塘景观 ${ }^{[17]}$ 、山西 大寨梯田景观 ${ }^{118}$ 等。上述研究为一系列有关区域城市生态基础设施、绿 色廊道、遗产地保护的规划研究项目提供了重要参考 ${ }^{[19-[21]}$, 同时通过 与规划设计实践相结合, 诞生了一系列以 “田” 为主题的景观设计作 品, 如 “田”一一北京奥林匹克森林公园及中心区景观设计、“长林 in contemporary landscape planning and design. Although it is recognized that, along with social and cultural shifts, economic growth, and technological advance, there are some limits of applying traditional eco-wisdom in the contemporary context, traditional wisdom shows its universality beyond time changes. For example, the philosophy in traditional eco-wisdom is consistent with modern ecological concepts adapting to natural environments and establishing a harmonious human-land relationship. Therefore, the revival of traditional eco-wisdom requires us to be aware of the limits and universalities, and to translate, innovate, and develop new eco-wisdom to meet contemporary social and cultural needs.

\section{Research Results}

\subsection{Agricultural Landscape}

Agricultural landscape is the most representative landscape shaped by the human-land interaction in China's agricultural civilization and characterized for its poetic, pastoral appearance and sustainable, productive functions. The incredible empirical knowledge in the traditional agricultural landscapes involves landscape planning, design, construction, and management, embodying ecological philosophies such as adapting with environmental changes, living modestly, and recycling water and other resources. It also offers a variety of landscape typologies to support modern landscape theoretical study and design ${ }^{[11]}$.

LA PKU first studied the Hani terraces in the Honghe area of Yunnan that are shaped by the locals' environmental-adaptive practice. Hani people are used to protecting alpine forests of 2,000 $\mathrm{m}$ above sea level to collect rainwater, conserve water sources, and irrigate terraced farmlands on the hillsides ${ }^{[12][13]}$; the agricultural landscape in the West Sichuan Plain is an example showing ancient water management practice, which created a productive, rich plain area by building water conservancy and irrigation systems centered in Dujiangyan with fish-mouth levees, overtopping dams, and aqueducts and channels — such eco-wisdom was introduced into the design of the Dujiangyan Water Culture Square (Fig. 3) ) $^{[14]}$. LA PKU also studied traditional waterfront forest landscapes ${ }^{[15]}$, the agricultural landscape in North China Plain consisting of shelter forest networks and dry farmlands ${ }^{[16]}$, the mulberry-pond landscape in Magang of Guangdong ${ }^{[17]}$, the Dazhai terraces in Shanxi ${ }^{[18]}$, etc. These studies provide important reference for a series of planning research projects ranging from regional urban ecoinfrastructure and green corridors to heritage protection ${ }^{[19][21]}$, and inspire a number of design projects themed on farming landscape, such as the planning of the Beijing Olympic Forest 
方田”一一北京首都国际机场 3 号航站楼楼前区景观与城市设计、“福 田”一深圳中心区景观设计等，这些设计不仅尝试将 “田”本身富 于美学韵律感的形式和肌理融人设计之中, 更探索了造田、灌溉、种 植等传统农业经验技术在设计中的应用（图4 [ $^{[16]}$ 。

俞孔坚就传统农业实践对当代景观设计的启发进行了梳理，将其 总结为 “农民的途径”。这些策略包括充分利用周边有限的资源、可 持续地利用资源、以最小投人实现最大收益、重视人的尺度、适应 自然过程和季候节律等。具体策略按传统农业的主要实践活动可分 为 4 类:

1 ) 造田和地形整理: 传统农业的地形整理有着服务于农业生产、 作物种植的功能性目的，通过在实践中采用适应地形、就地填挖方平 衡的方法, 以减少人力和物料运输的投人;

2 ) 灌溉与水管理: 传统灌溉方式主要依赖重力进行组织, 紧密结 合地形与原有水系格局，构建了农业景观中最为复杂精巧的部分，以 水渠、垄沟、塘堰、畦田等构成的半自然、半人工的水系统与相关的 用水活动、精神信仰共同塑造了丰富多样的水利文化景观;

3 ) 施肥与土壤改良: 传统农业将人畜粪便、秸秆等有机废物用 作肥料, 以保持土壤肥力并构建完整的养分循环。而现代城市景观中 化肥的大量施用不仅打破了这种养分循环，还使得 “肥料” 成为 “污 染”，造成城市河湖富营养化问题;

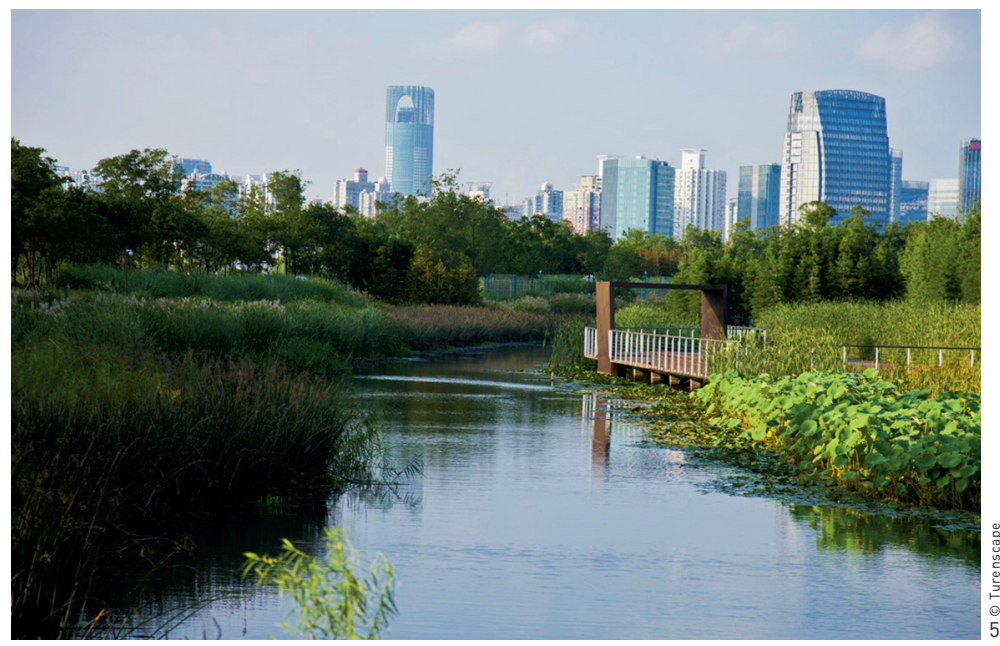

Park and the landscape design of the central area, the landscape and urban design of the Beijing Capital International Airport Terminal 3, and the landscape design of Shenzhen central area. These projects not only integrated rich aesthetic forms and fabric of agricultural landscape with modern design methods, but also creatively introduced traditional agricultural activities, such as farmland reclamation, irrigation, and planting, into contemporary landscape design (Fig. 4) ${ }^{[16]}$.

By studying how traditional agricultural practices can inspire and be applied in contemporary landscape design, Yu developed a series of design strategies, called "peasants' approaches," including making the best use of limited resources and operating sustainably, realizing maximum harvest with minimum investment, serving on a human-scale, and adapting to natural processes and solar terms. These strategies can be summarized into four categories:

1) Farmland reclamation and leveling: landform leveling is necessary for crop planting and production, which often adopts on-site cut-and-fill to reduce labor and material transportation;

2) Irrigation and water management: as the most complicated and delicate agricultural facility, traditional gravityworking irrigation system, consisting of channels, ditches, ponds, lowlands, etc., is often closely integrated with local terrains and existing water systems, supporting water-related activities and spiritual beliefs and shaping a rich diversity of water-culture landscape;

3) Fertilization and soil improvement: in traditional farming, human and animal manure, crop straw, and other organic waste are often used as fertilizers to maintain soil fertility and nutrient circulation. However, the extensive use of chemical fertilizers in modern urban landscapes not only disturbs the nutrient

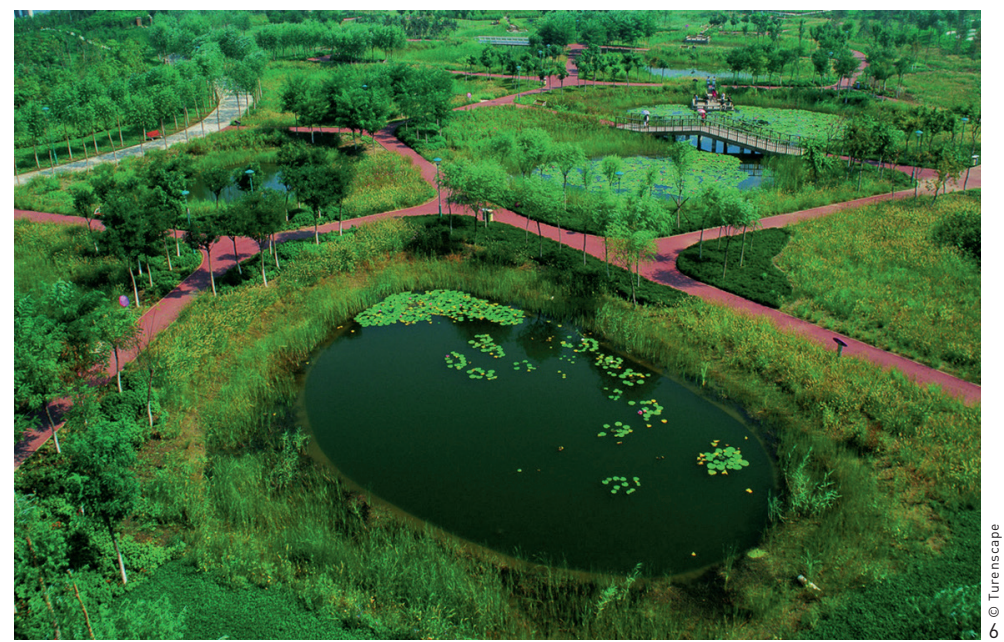



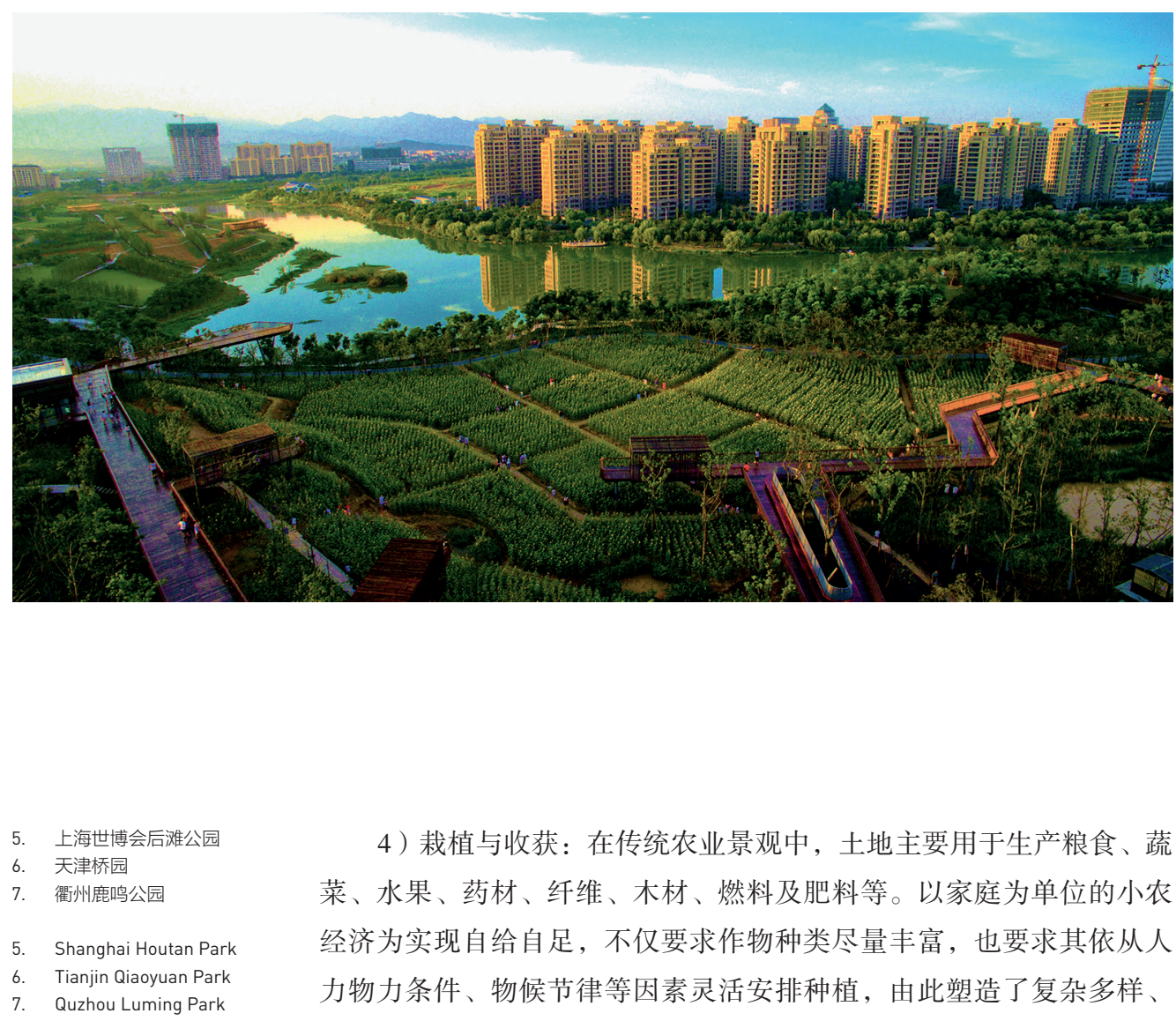

4 ) 栽植与收获: 在传统农业景观中, 土地主要用于生产粮食、蔬 菜、水果、药材、纤维、木材、燃料及肥料等。以家庭为单位的小农 经济为实现自给自足, 不仅要求作物种类尽量丰富, 也要求其依从人 力物力条件、物候节律等因素灵活安排种植, 由此塑造了复杂多样、 动态变化的农业景观。 ${ }^{[3][9]}$

这些 “农民的途径” 被创造性地应用到上海世博会后滩公园（图

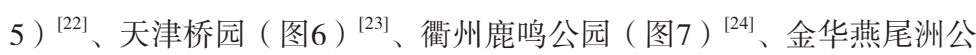
园（图8） ${ }^{[25]}$ 、哈尔滨群力雨洪公园（图9) ${ }^{[26]}$ 等一系列景观设计作品 中, 助力解决诸如雨洪管理、棕地修复、水质净化、都市农业等当代 城市景观中棘手且关键的生态设计课题。

\section{2 乡土聚落}

乡土聚落是典型的 “没有设计师的设计” ，是当地居民与地域 自然环境长期相互适应的物质形态，乡土聚落的选址、空间布局、建 筑形态等体现着丰富的传统生态智慧。对乡土聚落的研究绕不开中国 古代一门关于择居相地的特殊 “学问”——风水”。在早期对 “风 水” 的探讨中，俞孔坚就指出 “风水” 体现的是中国文化中的理想景 观模式，其源于农业定居文明对环境的长期适应。其中涉及对住宅、 村落、墓地的选址、朝向以及空间格局的思考，包含了丰富的环境适 应经验, 例如寻找和接近丰富的自然资源, 躲避洪水、泥石流、地震等 自然灾害与野兽侵袭，获得适宜的日照、开阔的视野和自然庇护等。 ${ }^{[4]}$

1998年以后, 在乡土景观研究的视野下, 北大景观针对传统聚落 开展了一系列研究, 其中较有代表性的是对西南、华南山地地区乡土 聚落和民居建筑的研究 ${ }^{[27]-[29]}$ 。对藏东乡土景观的研究在地域视野下 探讨了聚落和建筑与藏东独特自然环境的共生关系（图10）。该区域 内高山和峡谷的巨大海拔落差造就了当地气候的多样性, 形成了农牧 circulation, but also wastes the nutrients that could be used for farming and causes water contamination and eutrophication;

4) Planting and harvest: traditional agricultural landscapes produce grain, vegetables, fruits, medicinal plants, fibers, wood, fuels, and fertilizers. The small-scale peasant economy requires each family to be self-sufficient, not only producing a rich variety of crops, but also cultivating in accordance with solar terms and limited labor and materials. In doing so, a diverse, dynamic agricultural landscape is created. ${ }^{[3][9]}$

These "peasants' approaches" were creatively employed in the Shanghai Houtan Park (Fig. 5) ${ }^{[22]}$, Tianjin Qiaoyuan Park (Fig. 6) ${ }^{[23]}$, Quzhou Luming Park (Fig. 7) ${ }^{[24]}$, Jinhua Yanweizhou Park (Fig. 8) ${ }^{[25]}$, Harbin Qunli Wetland Park (Fig. 9) ${ }^{[26]}$, and other landscape design projects, to help solve the ecological issues in contemporary urban landscapes, including stormwater management, brownfield remediation, water purification, and urban farming.

\subsection{Vernacular Settlements}

China's vernacular settlements show a spontaneouslyformed physical setting that was shaped by the long-term interaction and adaptation between the inhabitants and local natural environments. A lot of traditional eco-wisdom is embodied in the location selection, spatial layout, and architectural forms. The study on vernacular settlements often closely associates with the philosophy of Feng-shui. Reported in his early publications, Yu pointed out that in Chinese culture, Feng-shui embraces a desire for ideal landscapes and lifestyles over humans' long-time adaptive exploration in the age of agricultural civilization of China. It guided the selection and design of dwellings, sites, villages, and cemeteries to access to natural resources, to avert natural disasters such as floods, mudslides, earthquakes and wild animal attacks, and to have good sunlight, open views, and shelters. ${ }^{[4]}$

Since 1998, by adopting the theoretical framework and research methods of vernacular landscapes, LA PKU has conducted a series of studies on China's traditional settlements, including the vernacular settlements and dwellings in the mountainous region of Southwest China and South China $^{[27] \sim 29]}$. For example, LA PKU examined the relationship of the settlements and architecture with the unique natural environment in the East Tibet through their investigation on the vernacular landscapes in the region (Fig. 10). Due to the huge altitude difference, the local climate is diverse and changing, resulting in a landscape of typical vertical zonality where farmlands and grazing lands are found: Most settlements were built on the hillsides of the valleys, with grazing lands, 
业共存、依海拔呈垂直地带性分布的典型景观：几乎所有的聚落都自 上而下地分布在河谷山簏，牧场位于上部、森林位于山腰、农田位于 谷地。由于河谷土地紧张, 村镇通常建于二级河流阶地以上、土地贫 痊、不适于农业生产的山坡或台地上，背山面河，向阳避风; 村镇的 空间形态多为带状、类带状布局, 以适应峡谷地形。[27]

对藏东乡土聚落的深人解读为在西藏自治区昌都市进行的一系列 城市设计项目提供了重要启示, 如其中的昌庆街改造项目充分回应了 当地气候条件、地理环境、资源、技术和人居方式。 ${ }^{[27]}$

对川西乡土聚落的研究反映在了北大景观2008年协助四川卧龙等 地进行的地震灾后重建工作中。在北大景观编写的《和谐生态家园重 建工作手册》中, 当地藏族、芫族乡土聚落的环境适应经验为一系列 有关村镇的有机分散式布局、适应地形地貌、避灾选址、水土保持, 以及建筑材料的选择提供了启示 (图11)。 ${ }^{[30]}$

\section{3 传统水适应性景观}

水问题是当代中国城市面临的最为棘手的环境问题之一。除了借 鉴西方国家已有的研究和实践外，中国传统治水、用水的经验智慧也 值得珍视和学习, 传统水适应性景观及其相关的传统智慧与实践也已 成为北大景观近年来最主要的研究方向之一 ( 图12)。这部分研究聚

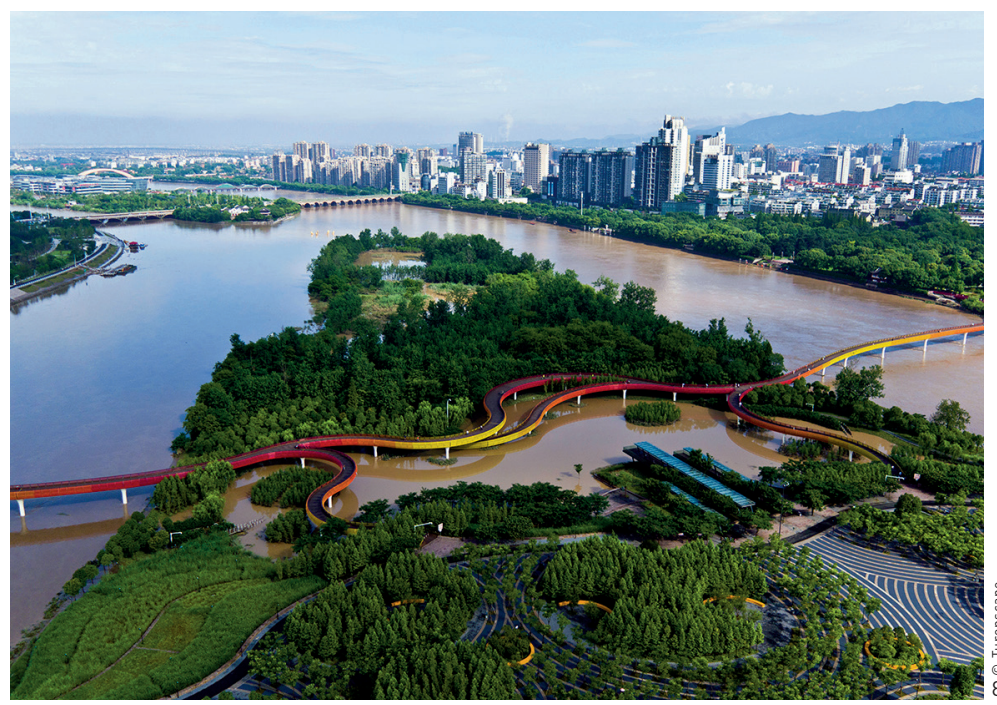

forests, and farmlands from the top to the bottom. Due to the limited land resource, most villages and towns sit on the banks of tributaries, slopes or terraces where the land is too poor to farm yet with natural shelters; the belt-like spatial patterns were developed along with the valley terrain. ${ }^{[27]}$

The research on the settlements in East Tibet provides an important reference for a plenty of urban design projects in Changdu, Tibet. For example, Changqing Street was reconstructed to adapt to the regional climate and physical environments with a respect to local resources, techniques, and lifestyle. $^{[27]}$

In 2008, LA PKU's study on the vernacular settlements in the West Sichuan informed the project of post-quake reconstruction planning of Wolong area. In the publication Handbook of Post-quake Eco-settlement Rebuilding, LA PKU reviewed the vernacular settlements of Tibetans and Qiang villages in order to offer references to other studies on village and town spatial pattern, adaptive landform making, disaster-averting construction, soil and water conservation, and construction material selection (Fig. 11). ${ }^{[30]}$

\subsection{Traditional Water-Adaptive Landscape}

Water-related problems are one of the most difficult and complicated environmental issues challenging contemporary Chinese cities. In addition to drawing lessons from existing studies and practices in West countries, the wisdom in China's traditional water management also offers valuable reference, particularly the traditional water-adaptive landscapes and related

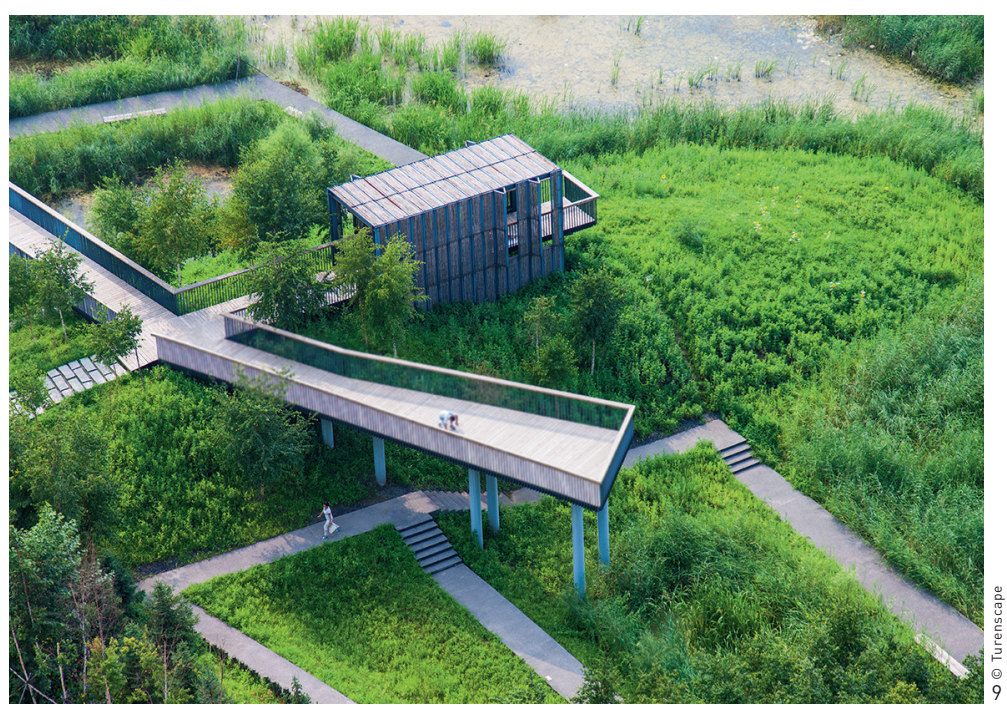



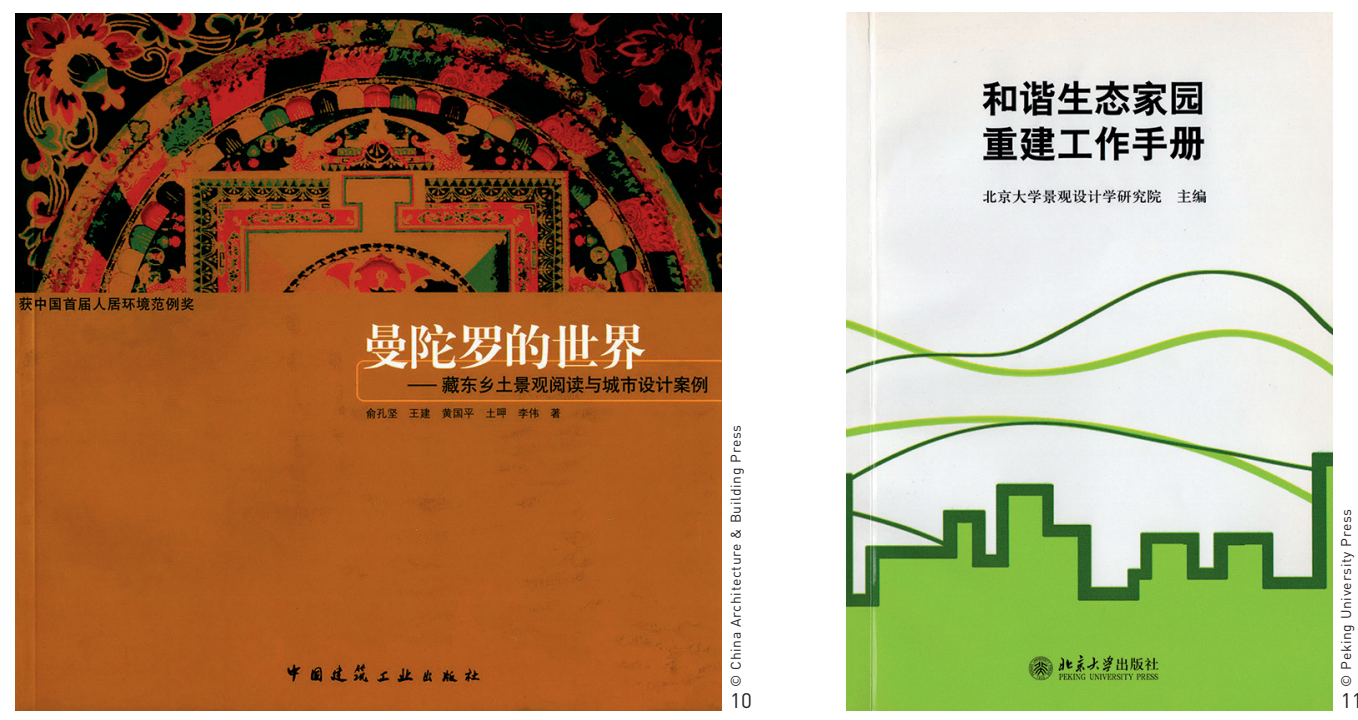

焦于水的利用、管理与灾害应对，涉及不同的地域和景观类型。代表 性研究成果包括:

\subsection{1 中国传统农业水适应性景观}

这部分研究梳理了中国从湿润到干旱不同地区、不同水资源条件 下的典型农业景观及其治水智慧。主要包括:

1 ）位于长江中下游平原、长江三角洲、珠江三角洲地区的圩田、 围田、基围景观：通过改造低洼的湿地平原，并采取筑围堤、设涵 闸、开沟渠等措施，有效实现了对水体的调蓄利用和旱涝适应，满足 了灌溉、排涝、种植、水产、水运等多种目标，创造了以桑基鱼塘等 为代表的传统可持续、生态循环农业的典范。 ${ }^{[31-[34]}$

2 ) 位于江淮地区人海口和滨海地区的沙田、涂田、潮田景观：通 过修筑海塘挡潮、开沟渠排涝、蓄淡水或引潮水灌溉，以及采用初种

金华燕尾洲公园

哈尔滨群力雨洪公园

10. 《曼陀罗的世界一藏 东乡土景观阅读与城市 设计案例》封面, 该书 于2004年出版。

11. 《和谐生态家园重建工 作手册》封面，该书于 2008年出版。

8. Jinhua Yanweizhou Park Harbin Qunli Wetland Park

10. Cover of The Mandala World-Interpreting the Vernacular Landscapes and Urban Design in East Tibet, published in 2004.

11. Cover of Handbook of Post-quake Ecosettlement Rebuilding. published in 2008. 水稗或养殖鱼虾等方法来脱盐等措施，实现了对滨海地区水土资源的 综合利用和对洪泛、潮汐自然过程的韧性适应。[31][35]

3 ) 华北平原的台田景观：华北半湿润、半干旱气候条件下的低 洼平原有着盐碱化的特殊问题, 以地处河北、河南、山东的黄河下游 平原和黄河三角洲最为典型。这一地区传统的台田景观通过一系列手 段实现了盐碱地的改良和水资源的调蓄利用，包括开挖沟渠池塘，以 排碱蓄淡、控制地下水位; 堆土抬地以控制反碱、满足农作物种植要 求; 养殖鱼虾以增加收益并提高脱盐改碱效果。[31][36]

4 ）甘肃、宁夏等中国西北部干旱地区的砂田景观：通过将河流中 的卵石、沙砾混合物覆盖在农田表面，可以起到拦蓄地表径流、减少 水土流失、蓄水保墒、抑制蒸发、防止风蚀和土地沙化等作用，有效 保护了当地稀缺的水土资源。[31]

5 ）中国南北方山地丘陵地区的梯田景观：主要包括黄河流域黄土 高原地区的旱作梯田和主要分布在云南、广西、四川、贵州等地的稻 eco-wisdom and practice that have become the core in LA PKU's recent research (Fig. 12), focusing on water use, management, and disaster-averting solutions in various landscape forms found in different regions throughout China. Representative research and findings include:

\subsubsection{Traditional Agricultural Water-Adaptive Landscape in China}

LA PKU has studied the typical agricultural landscapes and related eco-wisdom in China's traditional water management practice in both humid and dry regions with different water conditions:

1) The polder landscapes in the mid- and lower-basins of the Yangtze River, the Yangtze River Delta, and Pearl River Delta: by reclaiming low-lying wetland plains and building dykes, culverts and sluices, and channels, an adaptive multi-functional water management system is created that not only effectively supports irrigation, drainage, planting, aquatic production, and water transportation, but also creates a model of sustainable agriculture represented by the mulberry-pond landscapes. ${ }^{[31] \sim[34]}$

2) The tidal farmland landscapes in the estuaries and coastal areas of the Jianghuai region: a resilient multi-functional water management system is formed by building breakwaters, drainage systems, freshwater or high-tide water retention and irrigation networks, and introducing Echinochloa species or fish and shrimps for water desalting and soil improvement. Such system can support a comprehensive use of land and water resources in coastal areas that is adaptive to floods and tidal processes. ${ }^{[31][35]}$

3) The elevated farmlands in the North China Plain: due to the semi-humid and semi-arid climate in the region, the lowlying plain has often suffered from serious salinization problems, especially in the lower Yellow River Plain and the Yellow River Delta, covering Hebei, Henan, and Shandong. The traditional elevated farmlands and water resource utilization systems are formed by creating channels and ponds for water desalination, freshwater storage, and groundwater control, elevating farming ground to keep the crops with a certain distance from the alkaline groundwater, and farming fish and shrimps to increase yield and improve desalination. ${ }^{[31][36]}$

4) The sand-cover farmlands in the arid regions of Northwest China: by covering the farmland surface with pebbles and gravel-sand mixtures, such landscapes can slow runoffs, reduce water and soil loss, facilitate water conservation, reduce evaporation, prevent wind-erosion, and thus effectively protect the scarce water and land resources. ${ }^{[31]}$

5) The terraced farmlands in the hilly areas throughout China: such landscapes include the dry terraced fields on the 


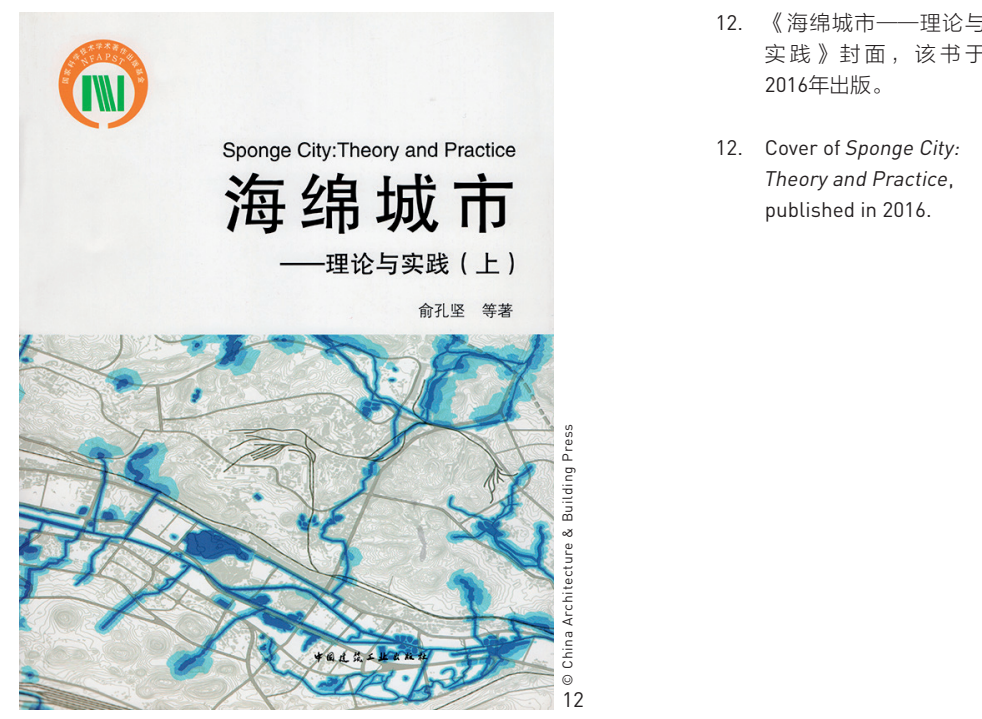

作梯田，这种由坡地改造而成、沿等高线修筑的带状台阶式田块具有 削减径流、蓄水保土、减洪减沙、水体自净等综合效能。[18][31]

与农田景观相关的水利景观也充分体现了中国古代的水适应智 慧。如以都江堰为代表的低堰引水技术, 在保障对河流自然水文过程 和生物过程最小干预的基础上, 实现了调蓄水量、防洪、供水灌溉等 多重功能。西北干旱地区的坎儿井引水灌溉技术, 则巧妙利用了高山 融雪和地下水, 通过坚井、地下暗渠系统汇集和输送地下水, 避免水 分大量蒸发。 ${ }^{[37]}$ 南方丘陵山区的陂塘景观, 是在山地丘陵暴雨山洪突 发、干旱易发等问题挑战下发展出的特有的旱涝适应性景观。其适应 性表现在：沿山地径流路径布置水田和堰塘以使集雨面积最大化、雨 洪水资源化; 利用山坳开怎冲田，预留排洪空间；坡地栽植需水量较 少的旱地作物以节水并保持水土。北大景观以重庆两江新区为例，模 拟了场地内陂塘系统的雨洪调蓄能力, 发现由塘和水田构成的陂塘系 统能够抵御百年一遇的 24 小时设计降雨。12年长期历史降雨模拟结果 显示，陂塘系统对场地径流的控制率高达 $75 \%$ 以上。 ${ }^{[38-[41]}$

中国不同地区各具特色的传统水适应性农业景观实现了对不同水 土资源的利用和对旱涝灾害的适应。这些因地制宜、与水为友的传统 智慧与当代片面依赖水利工程设施、“头痛医头、脚痛医脚” 的单一 目标水管理模式形成鲜明对比, 不仅能为当代农业景观的可持续建设 提供参考, 也能为当代城市水管理带来启示 ${ }^{[31]}$, 例如浙江台州永宁公 园 ${ }^{[2]}$ 、上海世博会后滩公园 ${ }^{[22]}$ 等景观设计项目。

\subsection{2 中国传统城镇水适应性景观}

城镇的形成和发展与水有着紧密的关系, 江河、渠网、湖池、水 泉等不同类型的水体为城市的供水、排水、交通等提供了诸多便利, 但也带来了旱涝灾害。对不同水环境条件趋利避害的适应过程塑造了 中国不同地区各具特色的城镇水适应性景观，表现在城镇选址、城市
Loess Plateau in the Yellow River Basin and the rice terraces in Yunnan, Guangxi, Sichuan, Guizhou, and other southern regions. The terraced farming fields are often built along samealtitude strips and can reduce runoffs, prevent water and soil loss, mitigate floods, reduce sediment, and help self-purification of water bodies. ${ }^{[18][31]}$

The related water-conservancy landscapes also embody rich ancient eco-wisdom of water adaptation. One of the representative cases is the low-dam water diversion system in Dujiangyan, which minimized human intervention on the natural hydrological and biological processes of rivers and served multiple functions such as water storage, flood control, and irrigation. Karez, another example, is a kind of water diversion system commonly seen in the arid region of Northwest China which collects melting snow and groundwater and reduces evaporation with shafts and underground culverts. ${ }^{[37]}$ The pond-network in the hilly regions of South China is also a unique landscape adaptive to extreme storms and droughts, which maximizes catchment areas through water-paddy fields and ponds along the runoff flow for a best reuse of rainwater, reclaims cols into productive fields where allows for natural flood drainage, and plants dryland crops that require less water to help save water and water and soil protection. LA PKU simulated the stormwater storage capacity of pond network in the Liangjiang New District of Chongqing. It was demonstrated that the water network consisting of ponds and paddy fields could withstand 24-hour-long 100-year storms and reduce runoff by at least $75 \%$ according to the local rainfall records of 12 years in history. ${ }^{[38] \sim[41]}$

The various traditional water-adaptive agricultural landscapes in different regions of China are shaped by Chinese people's practice to wisely utilize water and soil resource responding to droughts and floods. Different from most modern single-purpose engineering projects, such traditional water systems are developed in accordance with local natural and physical conditions, offering sustainable solutions for contemporary practice of agricultural landscape and urban water management ${ }^{[31]}$ like the Taizhou Yongning Park in Zhejiang $^{[42]}$ and Shanghai Houtan Park ${ }^{[22]}$.

\subsubsection{China's Traditional Water-Adaptive Landscapes in Cities} and Towns

The formation and development of cities and towns are often closely tied with water. Rivers, canals, lakes, and springs or wells provide many urban services such as water supply, drainage, and transportation, while threatening cities and towns with disasters. In the history that Chinese ancestors 
形态、城市水系和水利景观等多个层次。 ${ }^{[31][43]}$ 北大景观在全国范围内选 取了 214座传统城镇开展水适应性城市形态研究, 系统分析了传统城镇 水系的构成要素、结构特点及影响因素, 将传统城镇的水适应性平面 形态分为河网型、河渠型、湖池型三种结构类型。研究指出河网型 集中在东南沿海和长江三角洲低平原, 河渠型主要分布在山地和丘 陵城市, 湖池型则遍布全国, 其中, 华北平原城市的湖池型形态较为 典型。

太湖平原下游的传统城镇是典型的河网型水系形态。城市外部 因地制宜地修筑城墙抵挡洪水，形成不规则的城市轮廓; 内部则开挖 纵横的河网形成水陆相邻、河街平行的 “双棋盘” 格局, 其基本结构 为 “堤一水一闸” 构成的多尺度田字形格局，堤、水网和闸分别起到 挡水、蓄排和分级控制的作用，实现了水的排蓄利用和便捷的水运交 通，并能有效应对低洼易涝的灾害环境。[311-[34]

北大景观以华北平原中豫东平原上的 7 个古城为例，探讨了黄河洪 泛影响下湖池型水系的变迁和洪涝适应性景观的形成过程, 指出黄河 泛滥过程以及应对洪涝灾害的实践活动共同造就了三种典型的洪涝适 应性景观：以 “外圆内方” 为基本形态的城墙和护城堤；以堤外高于 堤内、堤内高于城内为特征的 “盘子底” 形城镇地形; 以湿地坑塘构 成的古城水系。这些典型景观背后蕴含着黄泛区传统城镇应对洪涝灾 害和水适应的经验智慧, 具体包括: 选择高地作为城址; 通过迁城 建筑迁址或改筑城墙等措施避开低洼内涝区域; 通过垫高地面避免洪 涝，并形成中间高、四周低的地势以利于排水; 将取土垫城与疏浚坑 塘洼地相结合，系统地整理城市地形; 设置由排水设施构成的排水系 统和由坑塘洼地形成的积水调蓄系统以应对内涝; 对城市坑塘湿地进 行综合利用，发挥其调蓄洪涝、纳污净化、农业生产、风景游皦、军 事防御等多项功能。[45\}-[47] in different regions utilized various water resources and eliminated hazards, diverse water-adaptive landscapes were shaped, showing great eco-wisdom in site selection, spatial form and pattern design, and water network and waterrelated landscape construction. ${ }^{[31][43]}$ Through an extensive research on 214 traditional cities and towns across the country where the spatial patterns and water networks were developed to adapt local water environments, LA PKU identified three typologies in terms of water network patterns, structural elements, and influencing factors, including 1) river or canalnetwork cities in the coastal areas of Southeast China and the low-plains of the Yangtze River Delta, 2) river cities in mountainous or hilly regions, and 3) lake cities that are found throughout China, particularly in the cities and towns in the North China Plain. ${ }^{[4]]}$

Most traditional cities and towns in the lower Taihu Lake Plain adopted canal-networks. City-walls were built according to local settings to prevent floods and thus the outer shapes were evolved irregularly; the inner water networks were often formed by introducing or digging crossed canals and a serial interval of water-land pattern. An "embankment-water-gate" grid structure was usually adopted which organized the spatial layout and served for flood prevention, water storage and drainage, and water regulation for different needs, not only realizing water smart-use and water transportation, but also effectively responding to the low-land flooding issue. ${ }^{[31] \sim[34]}$

LA PKU studied seven traditional towns in the East He'nan Plain, a part of the North China Plain, to explore the formation and evolution of the local lake networks and flood-adaptive landscapes under the influence of the Yellow River flooding. It was found that there were three types of flood-adaptive landscapes shaped both by the frequent floods and human's responding practice, they were: 1 ) a combination system of city-walls and round levees; 2) a bowl-like landform shaped by the flood silt long-time accumulated outside the city-walls and round levees; 3) a water system consisting of wetlands and ponds. The ecowisdom in such flood-adaptive landscapes were evidenced by selecting highlands for constructions and relocating conducts from low-lying areas, elevating ground to prevent floods and lowering the land around buildings and constructions to help drainage, combining ground elevation and dredging pond network to systematically organize landforms, creating resilient water drainage and storage systems to cope with waterlogging problems, and making best-use of the ponds and wetlands while providing multi-services like rainwater storage, pollution control, farming production, sightseeing and recreation, and military defense. ${ }^{[45] \sim 47]}$ 
北大景观进而探讨了作为黄泛平原古城典型洪涝适应性景观的 坑塘景观。研究者探讨了坑塘景观的形成过程, 指出黄泛泥沙沉积在 城墙和护城堤之外, 造成城内地势相对降低、积涝难排, 是城镇内部 坑塘形成的主要原因。在缺乏有效人工排水设施的时代，坑塘客观上 起到了吸纳雨污、解决内涝的作用, 是古城重要的 “绿色海绵”。在 豫东平原年蒸发量大于降雨量的半湿润、半干旱气候条件下，坑塘呈 现为一种具有干湿动态变化的半自然湿地生态系统。当地居民的农业 生产、用水活动、对盐碱和湖底淤泥的提取利用，以及休闲游惒活动 等, 均体现出坑塘景观对旱涝条件和季节变化的韧性适应, 建构了与 水涝为友、互惠共生的和谐关系。 ${ }^{[48]}$
As a representative typology of flood-adaptive landscape, pond-network landscapes were widely seen in the ancient towns in Yellow River Flood Plain. The findings revealed that the flood silt often deposited outside the city-walls and round levees, eventually resulting in the inner town area lay lower than the surrounding areas and difficult to drain. In the old days lacking of effective constructed drainage facilities, pondnetwork was developed and played a key role in detaining rainwater and runoff and mitigating waterlogging, acting as a "green sponge" in towns. In the East He'nan Plain where the annual evaporation was greater than annual precipitation and characterized for its semi-humid semi-arid climate, pondnetwork performed as a dynamic semi-natural wetland ecosystem resilient to droughts or floods. The local agricultural production, water use activities, extraction and utilization of alkali soil and lake sediment, as well as leisure and recreational activities, were all long-term adaptive practice to extreme natural events and seasonal changes by harmonizing with floods, instead of resisting. ${ }^{[4]}$

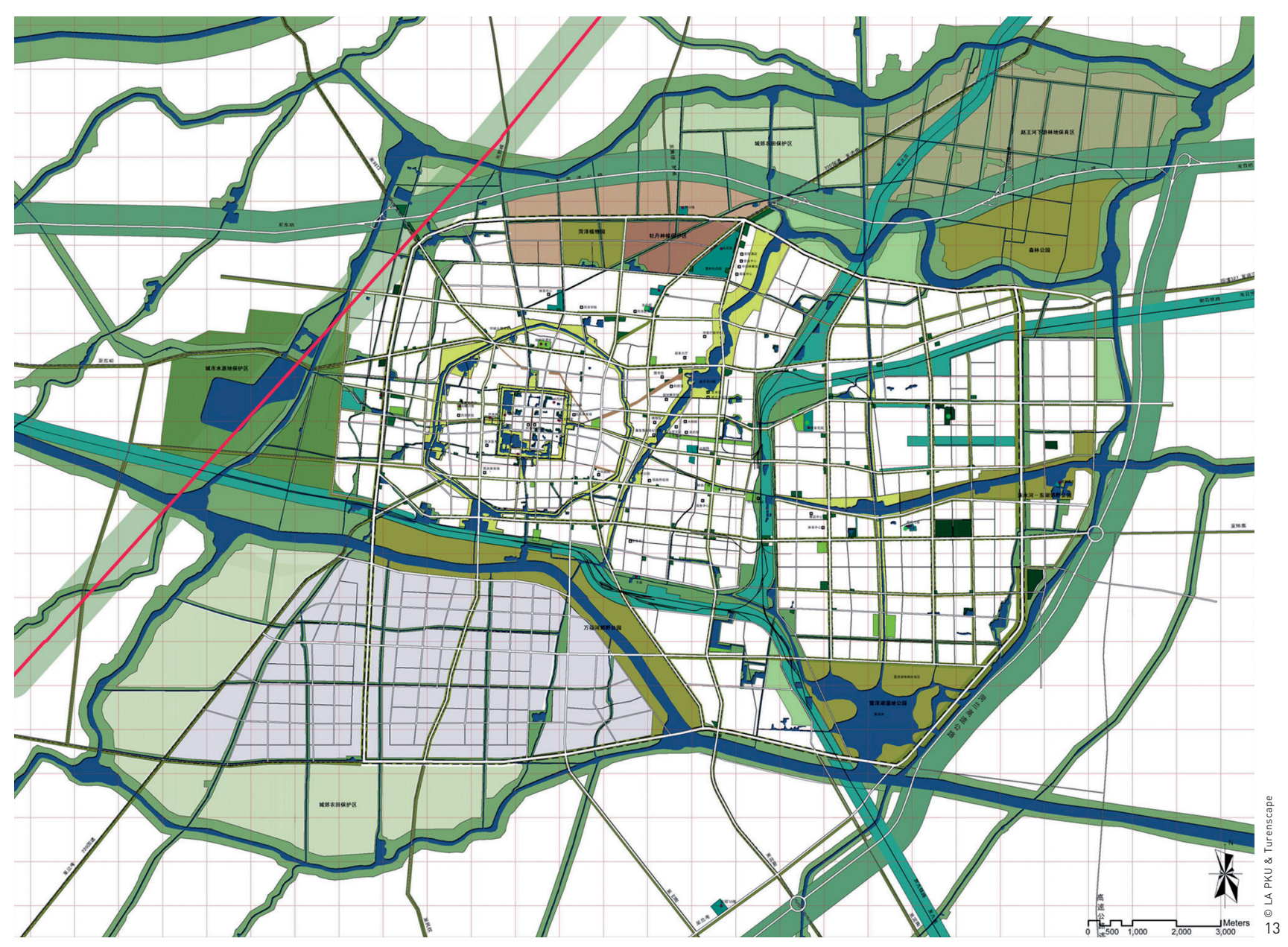

13. 山东菏泽生态基础设 计规划

14. 武汉五里界生态新城 规划

13. Infrastructure plan of He'ze, Shandong. 14. Wulijie Eco-Town Planning project in Wuhan, Hubei. 
中国不同地区古代城镇水适应的传统经验和智慧，特别是利用河 网、湖泊、坑塘等自然及半自然水体形成的以下渗、蓄留为主的水系 模式, 与当代城市大量依赖地下管网、以快速传输为特征的水系模式 形成了鲜明对比。前者能够综合发挥雨洪调蓄、水质净化、提供动植 物栖息地、农业生产、游㕰审美等生态系统服务功能, 后者则往往只 具有单一功能并难以适应自然水系统的动态变化和突发灾害。[49]这些经 验和智慧对当代中国 “海绵城市” 建设有着重要借鉴意义, 相关研究 成果被用于指导规划设计实践，如山东菏泽 “水城” 保护与建设规划

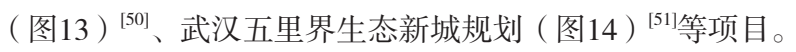

The traditional experience and eco-wisdom in water-adaptive practice in ancient cities and towns throughout China, especially the water systems based on local river networks, lakes, ponds, and other natural or semi-natural water bodies could efficiently support water infiltration, storage, purification, wildlife habitat-making, agricultural production, and recreational and aesthetical services. However, most modern urban water systems largely rely on grey infrastructures like underground pipe networks, and are constructed for single purpose which fail to adapt to the dynamic changes of natural water system and extreme disasters. ${ }^{[49]}$ It is believed that the traditional ecowisdom still holds a significance for the present-day Sponge City Construction in China. Some research results have been used to inform and guide many planning and design practices, such as the Water City protection and construction project in He'ze, Shandong (Fig. 13) ${ }^{[50]}$, and the Wulijie Eco-Town Planning project in Wuhan, Hubei (Fig. 14) $)^{[51]}$.

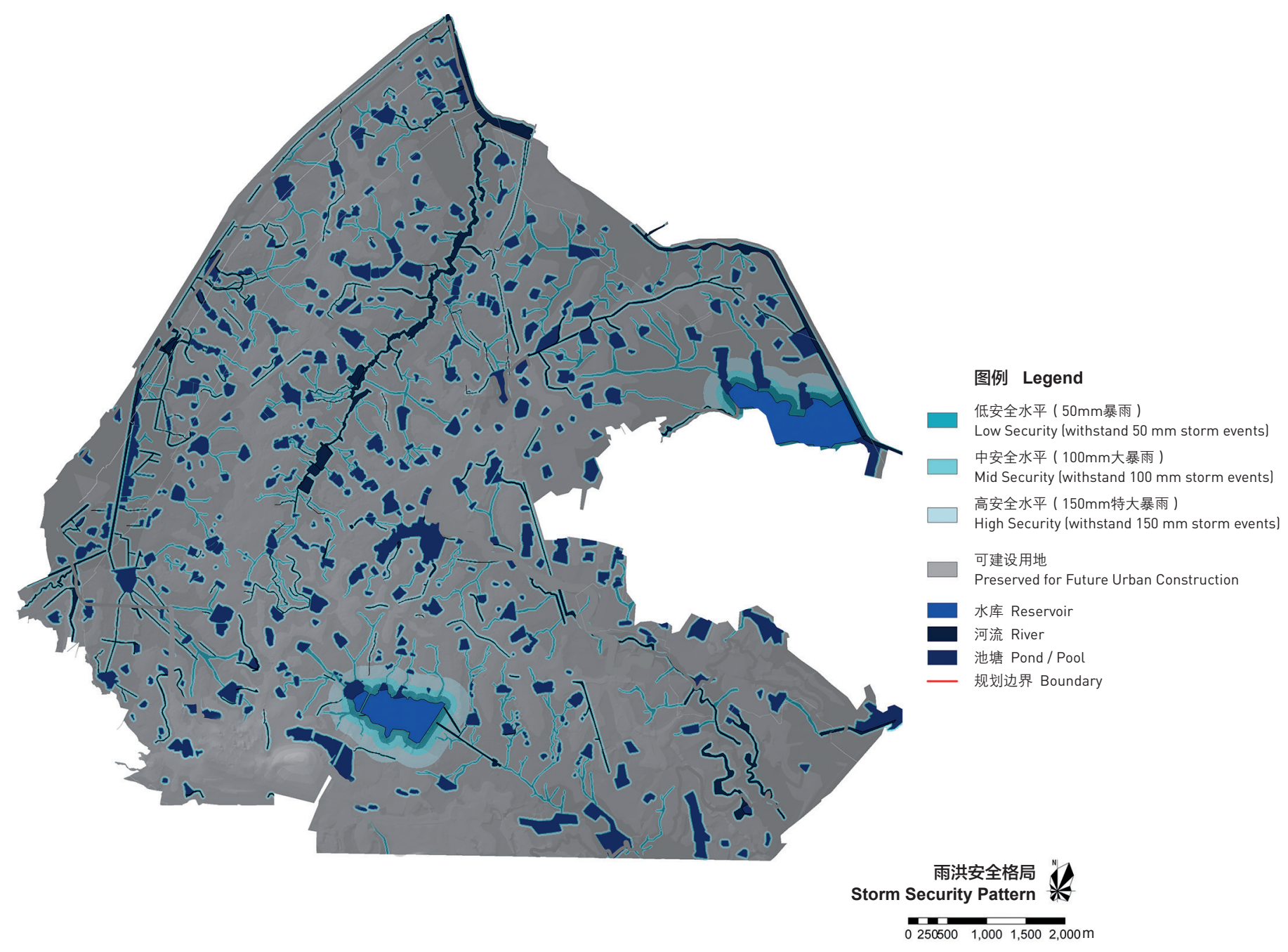




\section{4 结语与展望}

从理解 “风水” 到乡土景观研究、再到对中国传统的 “生存的艺 术”与 “深遂之形” 的探索, 北大景观始终保持着朴素而广阔的视野, 关注传统的田园、村落与城市, 关注人们的生产和生活, 关注在中国广 大而多样的自然环境背景下，不同地域人们适应土地和土地之上的自然 过程、精心维系人与自然互惠共生关系的经验和智慧。同时，北大景观 始终致力于将历史研究与解决中国当代环境问题和城市问题紧密结合, 赋予其研究主题和研究成果以重要的现实意义，并将这些研究成果创造 性地应用于规划设计实践——特别是在生态文明建设中, 这无疑是对中 国传统生态智慧最好的复兴、传承与发展。

\section{Conclusion and Prospect}

From the reinterpretation of Feng-shui to the study of vernacular landscapes, and to the exploration on China's ancient art of survival and the deep forms of landscapes, LA PKU's research covers a broad scope, concerning on China's villages and cities, as well as Chinese people's daily life and productive activities. LA PKU also have focused on the experience and wisdom in adapting to diverse regional settings and various natural processes and maintaining a mutualistic humanland relationship. At the same time, LA PKU has always been dedicated to integrating research on history with addressing the environmental and urban issues in contemporary China. The research themes and findings are often of great practical significance and have been applied creatively into relevant planning and design practices, especially to the current Ecological Civilization Construction, which is definitely offering an opportunity to rejuvenate, apply, and develop China's traditional eco-wisdom in nowadays agenda. LAF

\section{REFERENCES}

[1] Xiang, W. N. (2014). Doing Real and Permanent Good in Landscape and Urban Planning: Ecological Wisdom for Urban Sustainability. Landscape and Urban Planning, 121(1), 65-69.

[2] Wang, Z. F. (2017). Ecophronesis and Actionable Ecological Knowledge. Urban Planning International, (4), 16-21.

[3] Yu, K. J. (2017). Green Infrastructure through the Revival of Ancient Wisdom. The American Academy of Arts and Sciences Bulletin. Vol. LXX, No.4, 35-39. Retrieved from https:// www.amacad.org/multimedia/pdfs/publications/bulletin/ summer2017/bultetin_Summer2017_0tP-Infrastructure d d

[4] Yu, K. J (1998) The Ideal Landscapes - the Meanings of Feng-shui. Beijing: The Commercial Press.

[5] Yu, K. J., Wang, Z. F., \& Huang, G. P. (2005). Discussion about the Vernacular Landscapes and Their Implications to Modern Landscape Architecture. Huazhong Architecture, (4), 123-126.

[6] Yu, K. J. (2004). The Poetic Ordinary Landscape. Chinese Landscape Architecture, (12), 25-28.

[7] Yu, K. J. (2007). The Art of Terraces: Colloquial Landscape and New Vernacular Landscape. Urban Space Design. (6), 10-14.

[8] Yu, K. J. (2006). The Art of Survival: Positioning Landscape Architecture. Beijing: China Architecture \& Building Press.

[9] Yu, K. J. (2016). Creating Deep Forms in Urban Nature: The Peasant's Approach to Urban Design. In F. R. Steiner, G. F. Thompson, \& A. Carbonell (Eds.), Nature and Cities: The Ecological Imperative in Urban Design and Planning (pp. 95117). Cambridge, MA: Lincoln Institute of Land Policy.

[10] Yu, K. J. [2017]. Deep Forms for Beautiful China. Urban Environment Design, (6), 324-326.

[11] Yu, K. J. (2007). The Art of Terraces: Colloquial Landscape and
New Vernacular Landscape. Urban Space Design, (6), 10-14

[12] Wang, Z. F. (2001). Scenario Analysis of Significance of Vernacular Landscape - Take Hani Nationality Landscape for Example (Unpublished Master's thesis). Peking University, No. 5 Yiheyuan Road, Haidian District, Beijing

[13] Sun, P. (2001). Research on the Formation of Vernacular Landscape in Traditional Villages of the Han Nationality (Unpublished Master's thesis). Peking University, No.5 Yiheyuan Road, Haidian District, Beijing.

[14] Yu, K. J., Shi, Y., \& Pudau, M. (2004). People's Square: the Dujiangyan Square Case. Beijing: China Architecture \& Building Press.

[15] Yu, K. J., Li, D. H., \& Li, N. Y. (2006). The Evolution of Greenways in China. Landscape and Urban Planning, 76(1), 223-239.

[16] Yu, K. J., Liu, X. J., \& Li, H. (2005). Farmlands - People's Landscapes throughout China. Beijing: China Architecture \& Building Press.

[17] Pei, D. (2006). The Landscape Change of Dike-pond System under Rapid Urbanization - Take Magang, Shunde for Example (Master's thesis). Available from Wanfang databas

[18] Ji, T. (2007). Study on Terrace Landscape of China - Take Shanxi Dazhai and Yunnan Yuanyang for Example (Master's thesis). Available from Wanfang database.

[19] Yu, K. J., Li, D. H., \& Li, W. (2004). On Establishing the Great Canal Regional Ecological Infrastructure: Strategy and Approaches. Progress in Geography, 23(1), 1-12.

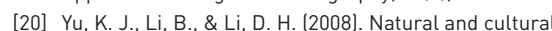
heritage area conservation based on ecological infrastructure
- take Fujian Wuyi Mountains for example. City Planning Review, 32(10), 88-91.

[21] Li. D. H . 2012) Greenway as National and Local Strategies: From National Ecological Infrastructure, China Grand Cana Heritage and Ecological Corridor to Urban-Rural Ecologica Network. Landscape Architecture, (3), 49-54.

[22] Yu, K. J. (2010). 2010 Shanghai Expo: The Houtan Park. Beijing: China Architecture \& Building Press.

[23] Yu, K. J., Shi, C., Wang, J., Qi, S., Hu, H. Y., Zhang, B., ... Jia, J. (2013). Bridge Garden in Tianjin Set the Nature into Action: Adaptive Pallet. Urban Environment Design, (5), 120-123.

[24] Yu, K. J. (2015). Harbin Qunli Wetland Park. In M. Wright (Ed), Rainwater Park: Stormwater Management and Utilization in Urban Park Landscape Design (pp.218-229). Guilin: Guangxi Normal University Press Group.

[25] Yu, K. J., Yu. H. Q., Song, Y., \& Zhou, S. M. (2015). Landscape of Resilience on the Design of Yanweizhou Park in Jinhua City. Architectural Journal, (4), 66-70.

[26] Yu, K. J. Liu, Y. J., \& Gao, Z. M. (2016). Above the Terrain and Water: Luming Park in Quzhou. Architectural Journal, (10). 30-37.

[27] Yu, K. J., Wang, J., Huang, G. P., Tu, X., \& Li, W. (2004). The Mandala World - Interpreting the Vernacular Landscapes and Urban Design in East Tibet. Beijing: China Architecture and Building Press.

[28] College of Architecture and Landscape of Peking University. (2014). Discover Beautiful China. Jiaju - Jiarong Tibetan Cultural Landscape in Western Sichuan. Manuscript submitted for publication. 
[29] Ren, L., \& Li, D. H. (2017). The Inheritance of Traditiona Settlement Space and Its Significance in Spontaneous Renewal of Rural Residential Building: A Case of Datangbian Village, Guangxi Province. Huazhong Architecture, (4), 13438.

[30] The Graduate School of Landscape Architecture of Peking University (Ed). (2008). Handbook of Post-quake Ecosettlement Rebuilding. Beijing: Peking University Press.

[31] Yu, K. J. (2016). Sponge City: Theory and Practice. Beijing: China Architecture and Building Press.

[32] Pei, D. (2013). Research on Flood-Adaptive Landscape of the Ancient City in Downstream of Taihu Lake Basin. Proceedings of Annual National Planning Conference 2013.

[33] Pei, D. (2014). Evolution and Mechanism of Flood-Adaptive Landscape in Downstream of Taihu Lake Basin (Doctoral dissertation). Retrieved from http://thesis.lib.pku.edu.cn/Usp/ aid $=$ META10926824\&cult $=$ CN

[34] Xie., Y. T. (2017). Restructuring Cultural Landscapes in Metropolitan Areas: A Typological Approach to Permanent Forms and Green-blue Infrastructure in the Yangtze River Delta Region in China (Doctoral thesis, Technische Universita Munchen, Munich, Germanyl. Retrieved from https:// mediatum.ub.tum.de/download/1378536/1378536.pdf

[35] Yun, H., \& Li, D. H. (2015). The Unique Heritage Value and Protection of Ancient Salt field in Danzhou. China Cultural Heritage, (4), 72-78.

[36] Luan, B. (2007). Research on the Landscape of Terrace Land Discussion on Its Form, Function and Value. Urban Space
Design, (6), 26-30

[37] Lu, X. X. (2016). Frontier Perception and Hydraulic Landscape of Xiyu-Xinjiang (Doctoral dissertation). Available from Wanfang Database.

[38] Jiang, Q. Z. (2015). The change of Beitang landscape's characteristics and functions and its application in mountainous city - a case study in Liangjiang New Area, Chongqing (Doctoral dissertation). Available from Wanfang Database.

[39] Yu, K. J., Jiang, Q. Z., Wang, Z. F. \& Li, M. H. (2015). The Research Progress and Prospect of Bei Tang Landscape. Areal Research and Development, 34(3), 130-136.

[40] Dai, Q. Q., \& Wang, Z. F. (2015). Modern Water Management of Pond-Paddy Field System in Chongqing. China Water Resources, (1), 34-37.

[41] Wang, Z. F., \& Zhu, G. L. (2017). A Study on Characteristic Changes and Causes of Pond Landscape Systems in the Process of Urbanization. Acta Scientiarum Naturalium Process of Urbanization. Acta Scientiarum

[42] Liu, H. L., Yu, K. J., Zhan, X. M., Li, C. B., \& Fang, W. L. $(2008)$ Flood-Control Planning Following Natural Hydrological Process: The Case Study of Yongningjiang River, Taizhou, Zhejiang. Urban Environment Design, (4), 29-33.

[43] Chen, Y. Y., \& Yu, K. J. (2015). Thought of Ancient "Sponge City": Experiences of Applying Water-Adaptive Landscape. China Water Resources, (17), 19-22.

[44] Chen, Y. Y. (2013). Traditional Urban River system in Chin Spatial Structure and Adaptive Mechanism (Doctoral dissertation). Retrieved from http://thesis.lib.pku.edu.cn/Usp/
apabi_usp/?pid=book.detail\&db=own\&dt=TASIMETA400\&cult $=$ CN\&metaid $=$ META 1001111237

[45] Yu, K. J., \& Zhang, L. (2007). The Flood and Waterlog Adaptive Landscapes in Ancient Chinese Cities in the Yellow River Basin. Urban Planning Forum, (5), 85-91.

[46] Yu, K. J., \& Zhang, L. (2008). Preservation and Development of Water Cities Adaptive to the Areas Flooded by the Yellow River. Journal of Hydraulic Engineering, (6), 688-696.

[47] Zhang, L. (2008). Floods and Waterlogging Disastrous Experiences and Adaptive - Landscapes of Ancient Cities in
the Yellow River Floodplain (Doctoral dissertation). Available the Yellow River Floodplain Wanfang Database

[48] Zhang, L. (2013). Traditional Green Infrastructure - The Wisdom of the Pond Landscape of Ancient City of Yellow River Flood Plain in North China. Water and Wastewater Engineering, (s1), 247-251.

[49] Xu, T. (2015). The Impact of Urban Green Space Pattern on Stormwater Regulation-Storage Potential and its Optimization (Doctoral dissertation). Retrieved from http://thesis.lib.pku.
edu.cn/Usp/apabi_usp/?pid=book.detail\&db=own\&dt=TASIME edu.cn/Usp/apabi_usp/?pid=book.detail\&db
TA400\&metaid=META1001111236\&cult=CN

[50] Yu, K. J., \& Zhang, L. (2007). Ecological infrastructure as unbuildable zone and urban green space system: a case study of Heze. City Planning Review, 31(12), 89-92.

[51] Yu, K. J., Zhang, Y., \& Liu, Y. Q. (2012). Ecologica Infrastructure Priority: Wuhan Wulijie Ecological City Case. Planners, 28(10), 26-29. 